\title{
Lisbon Stories: Migration, Community and Intercultural Relations in Contemporary Cinema and Literature
}

\author{
FERNANDO ARENAS
}

University of Michigan

\begin{abstract}
This essay focuses on immigration in contemporary Portugal and social phenomena related to community, intercultural relations, and citizenship as represented in acclaimed cinematic and literary texts. The objects of analysis are the Brazilian film Terra estrangeira (1996) by directors Walter Salles and Daniela Thomas, the Brazilian novel Estive em Lisboa e lembrei de você (2009) by Luiz Ruffato, and the Portuguese film Viagem a Portugal (2011) by Sérgio Tréfaut.
\end{abstract}

Keywords: Portugal; cinema; novel; Walter Salles; Luiz Ruffato; Sérgio Tréfaut

Migration played a significant role in the maritime-colonial expansion of Western European powers since the early modern era, through the forced migration of millions of Africans and a mixture of voluntary and forced migration of Europeans across the Atlantic to the Americas and Africa. Such was the case throughout the history of the Portuguese empire, as well as in postcolonial Brazil, Cape Verde, and Portugal. In the case of Brazil, successive waves of forced African and voluntary European migration (as well that from East Asia and the Middle East) constitute the foundation of the modern nationstate, alongside the native Amerindian population. Cape Verde is a diasporized nation-family par excellence, in that half of its population lives outside the 
archipelago. The Portuguese themselves have been migrating for more than five centuries. Throughout a long history of outward migration, however, there was an important interval shortly after Portugal's entry into the European Union, between the late 1980s and early 2000s, that witnessed the modernization and expansion of the Portuguese economy. Tens of thousands of Brazilians fled their country's economic crisis, while large numbers of Africans fled poverty and war (in the case of Angolans), and many Ukrainians left the economic precariousness of the post-Soviet era in search of new opportunities. Portugal became a recipient nation of immigrants (primarily from Brazil, former African colonies, Eastern Europe-Ukraine, Romania, Moldova-and China). 2015 figures provided by the annual report of the Serviço de Estrangeiros e Fronteiras pointed to 388,731 legal immigrants in Portugal (a decrease from 436,822 in 2011), of which $21.2 \%$ were Brazilian, making them the single largest nationality group (10). Since the late 2000s to the mid-2010s, there has been a decrease in the number of Eastern European and Brazilian immigrants residing in Portugal, primarily due to the country's economic crisis and ensuing high unemployment. ${ }^{1}$ As a result of the great economic recession since 2008, with severe consequences for countries such as Portugal, together with the emergence of Brazil and Angola as major economic powers, tens of thousands of Portuguese left for Angola and Brazil, as well as Mozambique, in a highly complex postcolonial migratory flow.

In this essay, I focus on the period before the 2008 economic crisis, a period that marks an inversion in the history of Portuguese migratory out-flow. During this time, Portugal became a recipient nation of Brazilian, African, and Eastern European migrants. My objective is to shed light on the complex intercultural dynamics between guests and hosts, as well as among guests, and their attempts at crossing the border or building new lives while forging communal links in a changing national and global landscape. My objects of analysis are the Brazilian film Terra estrangeira (1996) by Walter Salles and Daniela Thomas, the Brazilian novel Estive em Lisboa e lembrei de você (2009)

\footnotetext{
${ }^{1}$ A detailed report on the return to Brazil of Brazilian migrants residing in Portugal aired on TV Folha in 2012 ("Brasileiros fogem"). In the resort town of Costa da Caparica, near Lisbon, Brazilians accounted for $36 \%$ of the general population in 2006. By 2012, however, the percentage declined dramatically to $9.62 \%$. The report features images of abandoned shopping malls, empty stores, and half empty bars and cafés, underscoring the significant demographic and economic impact of the Brazilian exodus on small-town Portugal.
} 
by Luiz Ruffato, and the Portuguese film Viagem a Portugal (2011) by Sérgio Tréfaut. These texts focus on the experience of migrants in Portugal throughout the 1990s and 2000s, a time when the Portuguese economy was awash in European Union structural funds that propelled massive infrastructural projects throughout the country, and Brazil-especially between the early-to-mid1990s - was undergoing one of its worst economic crises ever, sending hundreds of thousands of migrants to North America, Europe, Japan, and Australia. Brazilians have constituted the largest immigrant/ethnic group in Portugal, in large measure due to common historical, linguistic, and cultural links between both nations, together with special Luso-Brazilian treaties of "friendship, cooperation, and consultation" signed at various junctures. ${ }^{2}$

There is a rich conversation between Terra estrangeira, Estive em Lisboa e lembrei de você, and Viagem a Portugal regarding the dynamics of immigration in contemporary Portugal. All three texts underscore the injustices suffered by immigrants, especially lower-income immigrants, in their new country as well as in their countries of origin. To varying degrees, they point to phenotypic/racial as well as linguistic/cultural hierarchies at work among different immigrants (e.g., Brazilians of different skin colors and classes, black Africans, and light-skinned Eastern Europeans) that shape the lives of individuals and groups. Characters are often caught in a web of illegal traffic in humans, drugs, and precious stones, and so those who are naive, ignorant, or in desperate situations commonly become trapped in ruthlessly exploitative situations that often lead to personal catastrophe. Migrants also encounter situations of utter helplessness as they face the power of the state when crossing national borders.

The works by Salles/Thomas and Ruffato intervene directly in the evolving historical, cultural, economic, and social relations between Brazilians and the Portuguese at the everyday interpersonal level, going beyond the usual diplomatic platitudes of their respective governments. They capture an important phase of this ongoing transatlantic and transhistorical relationship

\footnotetext{
${ }^{2}$ The following are examples of such special Luso-Brazilian treaties: "Acordo de facilitação e circulação de pessoas" (2003), whereby citizens of Brazil and Portugal are automatically granted 90-day visas to sojourn in either country; "Acordo sobre contratação recíproca de nacionais" (2000), whereby citizens of either country can be hired by Brazilian and Portuguese companies or might otherwise work in any professional field that is not forbidden by the host nation.
} 
while challenging the idea of a privileged, harmonious, and fluid relationship between the two countries, as well as among Lusophone cultures in general. While there are numerous instances of a cordial, hospitable, and even intimate relationship between Portuguese, Brazilian, and Lusophone African characters, experiences of uncanniness, cultural distance, and "disidentification" are also part of the interpersonal dynamics between Lusophone subjects. The notion of community in this case reflects not only what brings about convergence or what unites, but also that which effects "divergence" in a "common non-belonging," in the words of Roberto Esposito (139). Community, according to Esposito, would entail not a "homogeneous totality" (147) but rather "an interval of difference" (139). As pointed out by Christina McMahon in her rich ethnographic study of theater festivals in the Portuguese-speaking world, "productive tensions" (182) are constitutive of the lived experience of a Lusophone community through its "individual cultures and differing national identities," similarly to other transnational postcolonial communities based on common historical links and language (178).

\section{Terra estrangeira}

The point of departure for Salles and Thomas's starkly poetic and melancholic, black-and-white feature film is the collapse of the Brazilian economy in 1990 under former president Fernando Collor de Melo (he was eventually impeached in 1992). ${ }^{3}$ Salles considers this to be a watershed moment, not only for his generation, but also for Brazil (Almeida 30). He believes this to be the first time in its history that Brazil shifted from being a country of immigration to a country of emigration (Strecker 104). As a drastic measure to combat hyperinflation, the finance minister at the time, Zélia Cardoso de Mello, froze all checking and savings accounts. In Salles and Thomas's film, this draconian measure leads to the death by heart attack of the lower-middle-class mother of Paco, one of the film's young protagonists. This loss causes his life, then transitioning from high school to college and an aspiring acting career, to implode. Left alone in a highly precarious economic situation amid a gritty and

\footnotetext{
${ }^{3}$ I would like to thank Maria Carlota Bruno from Videofilmes for granting permission to use film stills of Terra estrangeira in this article.
} 
depressed São Paulo, Paco searches for a direction to his life. He eventually falls prey to Igor, an antique dealer who recruits Paco to deliver to Europe a "rare violin" that, unknown to Paco, contains cut diamonds. This entices Paco, as he had shared with his mother the dream of visiting her homeland in the Basque Country. Paco ends up in Lisbon, where he meets Alex, a Brazilian immigrant who works as a waitress. ${ }^{4}$ Her fragile existence takes a sharp turn when she storms out of the restaurant where she works after her boss makes disparaging comments regarding the supposed laziness of Brazilians. At the same time, she abandons her boyfriend, Miguel, a Brazilian jazz musician who is also a heroin addict involved in drug and diamond trafficking. He is eventually murdered over the violin that Paco is meant to deliver. Alex and Paco's lives spiral out of control as they flee from the drug and diamond traffickers who are after Paco's violin, which has fallen into the wrong hands. The film's denouement involves Alex and Paco on the road toward the Spanish border to elude the thugs pursuing them. Both characters become shipwrecked amid this perilous existential, economic, and criminal storm.

The iconic image of a half-sunken ship, juxtaposed with the couple embracing, constitutes a powerful symbol of the fate of Paco and Alex as victims of forces beyond their control. They are left alone with each other as the ultimate horizon of love and hope, even as they founder. The image of the abandoned ship (filmed off the coast of São Vicente island in Cape Verde) also symbolizes the impasse in Brazil's national trajectory during this time while conveying a sense of mourning and national loss. It likewise underscores the precarious nature of life at the center of a former empire that long ago lost its wealth and power (Oricchio 70).

In the end, Alex feels exiled from Brazil, a country that offered few opportunities in the early 1990s, while she simultaneously experiences an acute sense of alienation vis-à-vis Portugal. She in fact experiences a "double disidentification" regarding Brazil and Portugal, as both have become a "foreign land" from which she is existentially, emotionally, and economically exiled (Rosello 5; Strecker 103). Darlene Sadlier describes this dynamic as dépaysement, a term that denotes "leaving the homeland" and brings with it a

\footnotetext{
${ }^{4}$ Most Brazilian immigrants in Portugal, especially women, work in the service sector. See António and Policarpo 71.
} 
keen sense of "cognitive estrangement" (146). Alexandra Pinho also points to a loss of home that Paco and Alex experience both spatially and affectively (90).

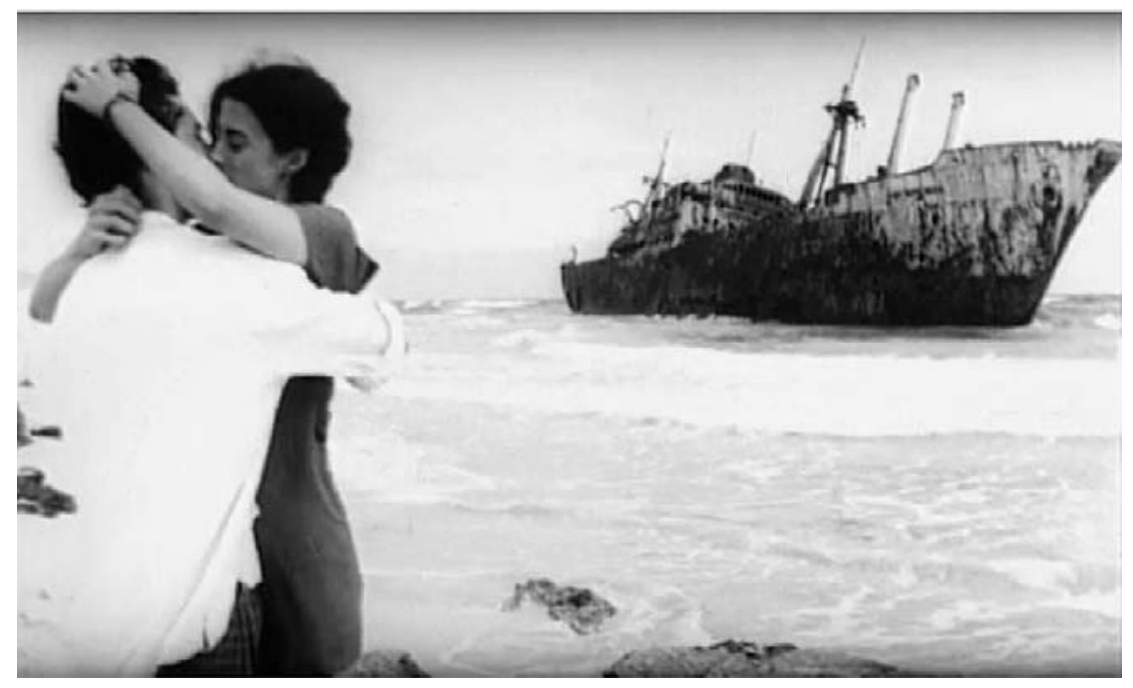

In an act of financial desperation, Alex offers her Brazilian passport for sale on the black market. She asks for three thousand dollars, but she receives only a small fraction of this amount, a fact that reflects Brazil's dramatic loss of economic, geopolitical, and symbolic prestige during this period. In a highly suggestive landscape scene in which Alex and Paco overlook the vast expanse of the Atlantic Ocean, there is a dramatic high-angle crane shot sequence in which the camera at first hovers vertically over the promontory to establish a view of the coastline. The camera then slowly retreats to show Alex and Paco high up on the edge of the continent, a shot that establishes a horizontal view through a wide-angle lens and places the characters in the middle-space between land and ocean. Their bodies seem at first overwhelmed by the magnitude of this setting as well as its historical implications. In a forward movement opening her arms, Alex exclaims, "Isso aqui, ó, é o fim!” As Sadlier points out, Alex echoes here the belief held by many until the later Middle Ages that the edge of Europe was indeed the end of the world (149). In a subversive gesture, however, as the camera moves back to allow Alex to ponder history, she does not lament the conquest of the New World from an anti- 
colonial standpoint. She instead expresses pity for the Portuguese for having "discovered" Brazil: "Coitados dos portugueses, acabaram descobrindo Brasil." Paco then giggles and Alex asks him: "Tá rindo de quê?"5

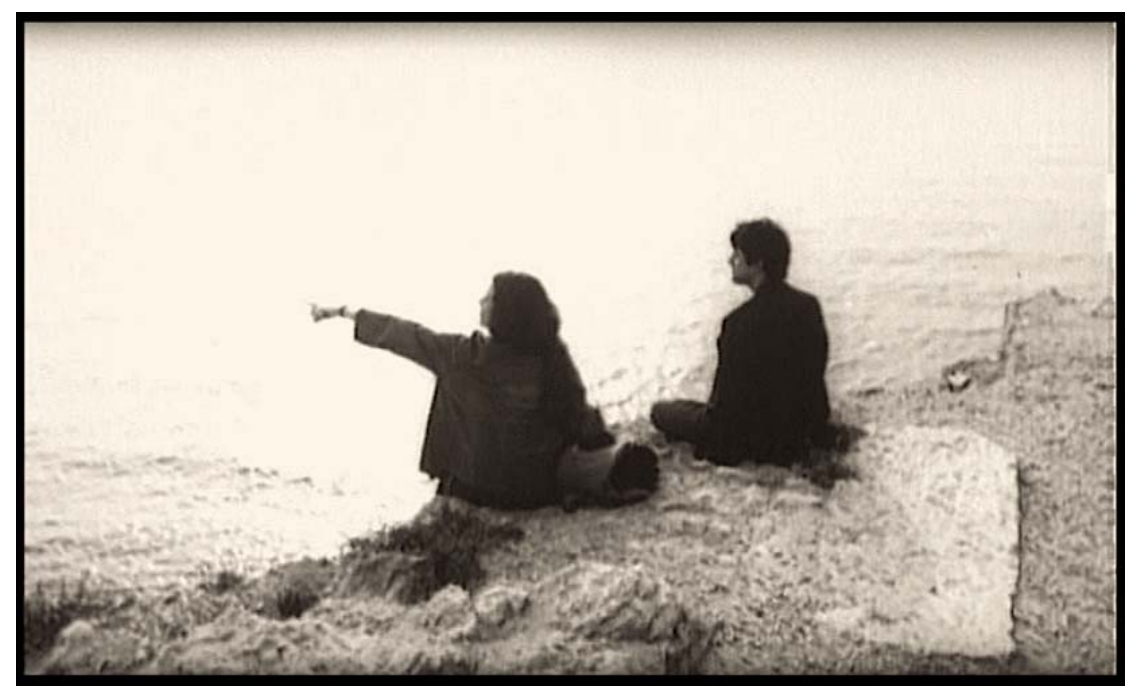

The ironic pity in Alex's comment and Paco's mocking response reveal a shared despondence toward both Portugal and Brazil and the devalued worth of each country in the characters' minds. Lúcia Nagib astutely points out that this dialogue inverts the logic of Brazil's primary foundational myth of "earthly paradise" by presenting Brazil as a curse for the Portuguese, a view refracted through the prism of hopelessness of young Brazilians in the early 1990s (169).

Alex is aware of her "foreignness" as a Brazilian immigrant in Portugal, due not only to her experience of discrimination in the workplace but also to her everyday social interactions. In a conversation with Miguel, she claims, "Quanto mais o tempo passa, mais me sinto estrangeira. Cada vez mais tenho consciência do meu sotaque. De que minha voz é uma ofensa ao ouvido deles."

Alex's experience casts a shadow of skepticism on ideologies of affect such as Lusotropicalism and notions of cordiality, as well as on the sense of mutual identification and co-belonging to a postcolonial community of Lusophone

\footnotetext{
${ }^{5}$ I would like to thank David Asselstine for always being an astute interlocutor as we discussed this particular scene.
} 
nations. Such skepticism is also operational in Paco's encounters with his Angolan neighbors. Most newcomers arriving in Lisbon, including Brazilians, who are unfamiliar with Portuguese modern history and culture, are invariably surprised at the large presence of Africans. In fact, the discovery of Africa in Portugal on the part of the directors and crew of Terra estrangeira forced them to change a script that would have focused solely on the experience of Brazilians in the former metropole to a script that incorporated a wider postcolonial Lusophone experience in contemporary Portugal (Strecker 106). Today the cosmopolitan city of Lisbon is the de facto cultural center of the Lusophone world, with a significant representation of people from all parts of the former Portuguese empire. Paco thus experiences a dual culture shock as he encounters not only the reality of Portugal but also the reality of Africans in Portugal. When he meets his boisterous and colorfully attired Angolan neighbors with their differently cadenced Portuguese, infused with Kimbundu and Umbundu terms, Paco appears somewhat disoriented, revealing the lack of seamless commonality among Lusophone subjects - in this case, black Angolans and white Brazilians - while at the same time laying bare linguistic, cultural, and racial fault lines at the heart of lusofonia. ${ }^{6}$ Paco, in the end, becomes objectified as a "Brazilian" and as a "white person" by black Angolans and white Portuguese alike. As the white Portuguese receptionist walks up the stairs to show Paco his hotel room, they cross paths with a young black African man. The receptionist remarks that "Eles não têm nada a ver conosco," since blacks board on the building's third floor, and the hotel where Paco will stay is located on the second. The context in which the receptionist utters this statement allows for a double reading. It can be read as "they are not part of our hotel," or it can also be interpreted as "they are not part of us" (i.e., the same "racial family" that would presumably include white Brazilians). This seemingly casual remark is ultimately overdetermined ideologically: it not only

\footnotetext{
${ }^{6}$ Both Lúcia Nagib $(163,177)$ and Alexandra Pinho $(91)$ refer to a "Portuguese Creole" spoken by Africans in Salles and Thomas's film. In reality, the African characters speak a distinctly Angolan variant of Portuguese which is peppered by lexical items stemming from national languages such as Kimbundu, Umbundu, Kikongo, among others. This is not a Creole language such as those spoken in Cape Verde, Guinea-Bissau, or São Tomé e Príncipe. Such critical misrecognition interestingly parallels that of the filmmakers themselves and many Brazilians and Portuguese with respect to African languages, as well as African ways of speaking Portuguese. This phenomenon reveals important gaps and fissures in the Lusophone community.
} 
points to an epidermic hierarchy at work in Portuguese society, but also to a social system of inclusion and exclusion whereby, depending on skin color and/or social class, one may or may not be perceived as closer to the majority white Portuguese population. The Angolan neighbors, on the other hand, remain aloof from Paco, since they are well aware of the fact that this particular hotel is notorious for illicit activities involving Brazilians. The Angolans suspect that Paco may be connected to such activities, and they let him know that they are not interested in the "makas" (problems) of white people (or "pulas" in Angolan Portuguese).

The socio-cultural dynamics featured in Terra estrangeira also entail crosscultural friendships, as well as hospitality, warmth, and solidarity towards Brazilian immigrants in Portugal. For instance, Pedro, a Portuguese music-store owner, is a good friend of Alex and her ex-boyfriend Miguel. He is fiercely loyal to Alex. When Alex seeks his help as she plans an escape from the drug and diamond mafia that will later pursue her (and Paco), he lends Alex his car and a gun, while showing her the safest escape route into Spain. A denizen of Lisbon's multicultural nightlife and a kind gay man, Pedro ultimately sacrifices his life for his Brazilian friends. Meanwhile, one of Paco's Angolan neighbors named Loli (played by Ângelo Torres, an actor from São Tomé) lends a hand by showing him the way to the supposed recipient of the violin he has carried all the way from São Paulo. ${ }^{7}$ When Loli first approaches Paco in the street, he senses that the latter mistrusts him. He tries to reassure him by stating, "Isto não é São Paulo ou Rio de Janeiro, meu!" (i.e., Lisbon is not unsafe and I am not a potential black criminal - an allusion to Brazil's well-known socioeconomic inequalities and underlying racism). Loli provides Paco with cautionary advice while at the same time offering a critical postcolonial African perspective on both Portugal and Brazil. In a casual conversation, Paco mentions to Loli that only strange things are happening to him in Lisbon. Loli asks him point blank: "Tavas à espera de quê em Lisboa, brasileiro?" Paco responds with, "Sei lá, no mínimo descobrir alguma coisa. Não foi daqui que eles saíram para descobrir o mundo inteiro?" Loli answers mockingly, pointing to Lisbon's famous suspension bridge over the Tagus River: "Portugal? Eles demoram três horas só

\footnotetext{
${ }^{7}$ Another factual error in Nagib's essay is the identity of the actor who portrays Loli. He is not Paris-based Malian filmmaker, José Laplaine but Lisbon-based San Tomean actor/filmmaker Ângelo Torres, whom I interviewed in 2012.
} 
para atravessar a puta da ponte, meu!" Paco's half naive and half self-ironic comment elicits in Loli a caustically humorous response that speaks volumes regarding the emotions many Africans harbor toward Portugal and their acute awareness of its degree of underdevelopment and peripheral status in world history. Lúcia Nagib accurately refers to the more realistic view that Africans have of modern Portugal in contrast to Brazilians (178).

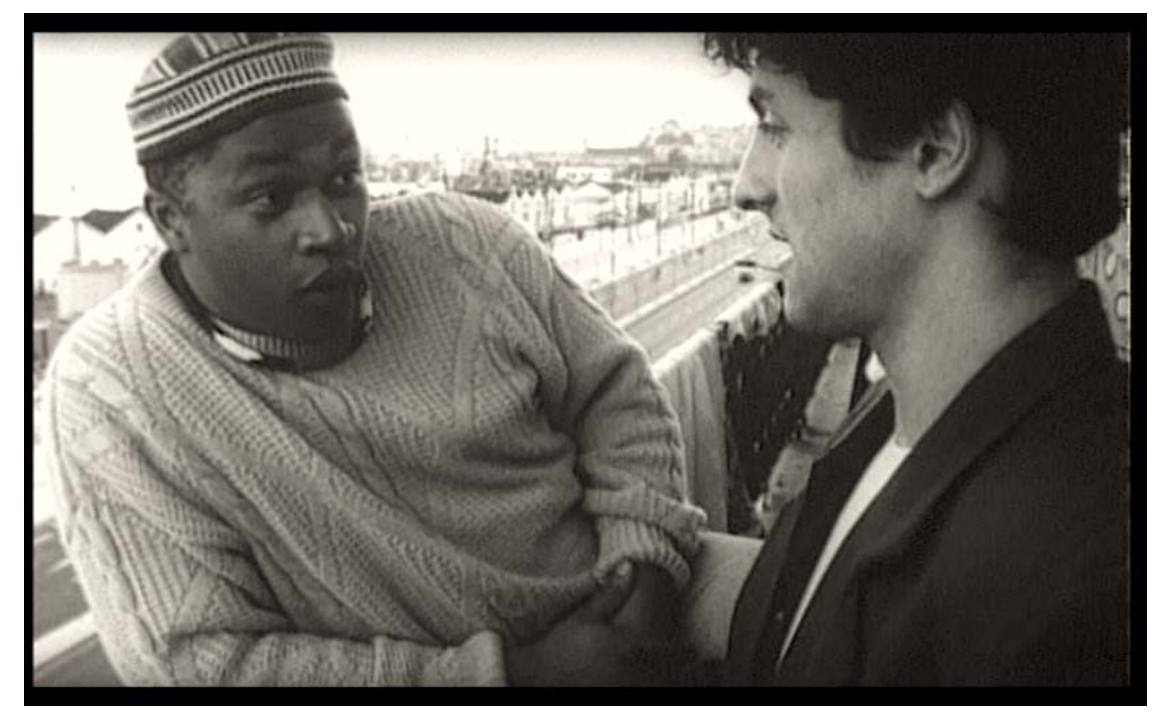

This is due to factors related to the time/space disjuncture between Portuguese decolonization of Brazil and that of Lusophone Africa, in addition to Brazil's often insular and parochial worldview (mostly due to its sheer size), which tends to manifest itself in a generalized lack of knowledge or familiarity with Portugal, as well as with Africa. Here, a Brazilian "guest" encounters an African "guest" who acts as a "host" and mediator vis-à-vis Portuguese culture, given the intimate knowledge that Lusophone Africans possess, at least relative to Brazilians, regarding Portugal.

\section{Estive em Lisboa}

Serginho, the protagonist of Luiz Ruffato's Estive em Lisboa e lembrei de você, is a working-class Brazilian immigrant with a basic education who has never 
traveled on an airplane. He also undergoes a significant cultural adjustment to life in Portugal. Part of this adjustment involves acquainting himself with Portugal's kaleidoscopic history, which includes the colonial empire in Africa and its aftermath as well as Portuguese migration throughout the world, including Brazil. Serginho engages in conversation with former Portuguese emigrants to Brazil and veterans of the African colonial/liberation wars, for example, and with a Portuguese man who made it rich in Brazil after decades of arduous work only to lose it all and return to Portugal. He also speaks with a former Portuguese soldier who fought in Mozambique and still suffers wounds at once physical and psychic; he expresses wonder that Portugal's former colonies were ultimately left to "the blacks" after "so much effort": "não entendia tanto esforço despendido pra depois abandonar as colónias aos pretos" (42). Serginho discovers that his black Angolan neighbor, a former peasant, was the victim of a landmine explosion during the liberation war in Angola. Having lost a leg, he had decided to migrate to Portugal with his wife and children. Unable to find employment, he decides to hire out his wife for sex. His life experience as a war victim contrasts dramatically with that of the war victors who now constitute the elite of postcolonial Angola, and Serginho is shocked to hear that the Angolan elites send their children to study in Portugal, live in the best neighborhoods, drive luxury cars, wear expensive clothing, and eat in the city's finest restaurants. He discovers that they are in fact the heirs to Portuguese colonialists, enjoying the oil and diamond wealth, while most Angolans live in poverty, much as they did under colonialism.

Serginho also witnesses the injustices wrought upon poor African migrants such as his Bissau-Guinean co-worker, Nino, who oversees the most thankless and arduous tasks in the restaurant where they work while suffering mistreatment from a racist Ukrainian waiter. Nino, as Serginho finds out, is at the bottom of the racial/color hierarchy in place at the restaurant where he works, while the university-educated, multilingual, and blonde, blue-eyed Ukrainian waiter, Anatolio, is the favorite of the restaurant management. In another context, due to his naiveté, Serginho falls prey to a scheming mixedrace Angolan, who is a loan shark trafficking in passports offered by desperate and naive immigrants. It is this scam that leads to Serginho's downfall.

Estive em Lisboa e lembrei de você, which revolves around Serginho's life experience, offers a vivid and multilayered portrait of contemporary Portuguese 
society from the point of view of a Brazilian migrant. ${ }^{8}$ Ruffato's novel, commissioned by Companhia das Letras (São Paulo) as part of their "Amores Expressos" collection of love stories, is allegedly based on the real-life saga of Sérgio de Souza Sampaio from Cataguases (Minas Gerais), ${ }^{9}$ who moves to Portugal a decade or so before the economic meltdown of 2007-08. Estive em Lisboa builds upon the central theme of Ruffato's five-volume novelistic cycle, Inferno provisório, which focuses largely on the modern historical trajectory of the Brazilian working class with an emphasis on its migratory path from rural to urban settings and from small to large urban areas in search of social, political, and economic citizenship. ${ }^{10}$ Migration, as Leila Lehnen points out (in line with James Holston's notion of citizenship in Brazilian society), represents a "mode of insurgency" within a national framework where citizenship is highly differentiated (18). Estive em Lisboa and Terra estrangeira both locate such insurgency within a global and postcolonial Lusophone framework.

Estive em Lisboa's Serginho idealizes Portugal while dreaming, like many other migrants, of job opportunities that may enable him to attain the goal of social mobility and a peaceful retirement with no material concerns. He enjoys the enthusiastic support of his community in pursuit of his dream, even as he desires to escape family-related financial troubles. The novel is a first-person narrative of Serginho's life before and after his adventurous trip to Portugal, and it is written in a lively heteroglossic prose style that captures the linguistic multi-dimensionality of Portuguese, much like Terra estrangeira. In Ruffato's work, one encounters the richness of the working-class mineiro variant of

\footnotetext{
${ }^{8}$ Brazil-based Portuguese filmmaker José Barahona directed the filmic version of Ruffato's novel Estive em Lisboa, released in 2015. The novel undergoes significant modifications in its screenplay adaptation. Serginho's background story in Cataguases, Minas Gerais, becomes much further developed than in the novel, while exhibiting rich poetic qualities in image and sound. The film also highlights Serginho's embeddedness in his community with deep emotional ties to his friends and family. Meanwhile, Serginho's migrant experience in Lisbon, as depicted by the film, centers on the experience of class disenfranchisement while the novel also underscores the racial and ethnic dimensions of the immigrant experience in Portugal. At the same time, Barahona's movie updates to 2015 the economic situation in both Portugal and Brazil, where neither country offered promises of a better life to its citizens or migrants.

${ }^{9}$ I would like to thank Leila Lehnen for alerting me to the narratological games that are intrinsic to the fictional works of Luiz Ruffato, whereby the author maintains his distance from the narration itself while affirming the semblance of realist representation.

${ }^{10}$ See Ruffato's Mamma, son tanto felice (2005), O mundo inimigo (2005), Vista parcial da noite (2006), O livro das impossibilidades (2008), and Domingos sem Deus (2012).
} 
Brazilian Portuguese, the Lisbon dialect of European Portuguese, as well as words and phrases in Bissau-Guinean and Cape Verdean (Portuguese-based) Creoles, in addition to Angolan Portuguese. In Salles and Thomas's film, one encounters Brazilian and Portuguese characters switching between dialects of Portuguese along with instances of spoken Angolan Portuguese.

Serginho violates the terms of his tourist visa by overstaying and by taking on work at a restaurant in the historic (and highly touristic) Bairro Alto district of Lisbon. He confesses at one point that he experienced significant personal and professional growth throughout his first year in Portugal. His life takes a double turn for the worse, however: he is laid off from his restaurant job, and then he loses his passport. Serginho loses his job in a blatant act of racial/ethnic discrimination, as he is immediately replaced by a newly-hired Ukrainian waiter. The restaurant owner alleges that the young Ukrainian man is better qualified and has a more appropriate physical appearance: "Não te ofendas, pá, os fregueses preferem ser atendidos por um gajo louro de olhos azuis. Eu cá até discordo, os brasileiros, mais cordatos, mas o cliente é quem manda" (81). Serginho, a mixed-race Brazilian man who has overstayed his visa, has no legal means to defend himself in this instance. To further complicate matters, he falls in love with a Brazilian sex worker, Sheila (from the state of Goiás), who may be enslaved to a global prostitution network. They bond around their common cultural and class roots in Brazil. Through her, Serginho witnesses first-hand the intense discrimination suffered by young Brazilian women in Portugal, especially those with darker skin. Sheila dreams of returning to Brazil having "made it" in Europe, and to realize her dream, she conjures up a plan to sell her passport. As with Alex in Terra estrangeira, however, she discovers that a Brazilian passport is not worth much. To help her, Serginho foolishly offers up his own passport, after which Sheila vanishes.

Serginho's empathetic point of view allows the reader a glimpse into the struggle of migrants in Lisbon and around the world. As Lehnen argues, people are often moved by the desire for social mobility and the benefits of citizenship - a concept that encompasses a "substantive distribution of rights, meanings, institutions, and practices" (Lehnen 46; Holston 7). Unfortunately, migrants often end up exchanging one scenario of disenfranchisement for another. There is a dramatic scene in Estive em Lisboa that takes place at a Western Union office near the Rossio, a place where thousands of migrants 
from different parts of the world congregate on a daily basis to nurture their respective community ties in their new "un/home": "pobres-diabos, africanos, árabes, indianos, babel de raças e cores" (73). ${ }^{11}$ Here Serginho describes an aging West African woman who faints in the middle of a phone conversation. She is aided by other migrants, and when she recovers, she yells out what Serginho poignantly interprets as her "desalento imigrante de quem sabe que de nada serve essa vida se a gente não pode nem mesmo aspirar ser enterrado no lugar próprio onde nasceu" (73).

\section{Viagem a Portugal}

While Terra estrangeira and Estive em Lisboa focus on dynamics of community building and intercultural relations between guests and hosts in contemporary Portuguese society, Tréfaut's Viagem a Portugal locates its story at the threshold of migration, at the precise point where travelers first meet the state. ${ }^{12}$ The action takes place at Faro International Airport, where a Ukrainian doctor, Maria (portrayed by astonishingly polyglot Maria de Medeiros), has arrived in order to reunite with her husband, Grégoire (played by the similarly multilingual actor Makena Diop), a Senegalese doctor. Voyage to Portugal takes place during a period of 24 hours on the eve of 1998, the year in which Lisbon hosted the 1998 World Expo. The event self-consciously celebrated Portugal's modernization within the context of the European Union while also underscoring the triumphs of oceanic navigation and "world building" celebrated by the state as Portugal's major contribution to the world.

The primary spatial setting of Viagem a Portugal is a small, cold, and allwhite interior room behind the doors of immigration control. Shot in austere black and white, the setting suggests an interstitial space cut off from the rest of

\footnotetext{
${ }^{11}$ For more on the concept of "un/home," see Knudson-Vilaseca.

${ }^{12}$ I would like to thank Tréfaut for granting me permission to use film clips from Viagem a Portugal in this article. An award-winning documentarian, Tréfaut directed the highly-acclaimed film Lisboetas (2004). The film offers a textured and visually poetic portrayal of the everyday life and struggles of immigrants in Lisbon that is quasi-ethnographic in scope, emphasizing the experience of Eastern Europeans and Brazilians. More recently, Tréfaut directed the acclaimed Alentejo, Alentejo (2014), which showcases in a hybrid musical-poetic-ethnographic documentary format the polyphonic and melismatic a capella musical style from the predominantly rural region south of Lisbon.
} 
the world, a sterile room that embodies the state power while emphasizing the fundamental distance from the nation of people entering not just Portugal but also the supranational space of the European Union. This space becomes the embodiment of the "camp" as conceptualized by Giorgio Agamben in Homo Sacer, where a state of exception is operational, a space in which "the normal order is de facto suspended" and abuses are committed with little or no accountability. Such "camps" do not depend on law but rather only on "the civility and ethical sense of the police who temporarily act as sovereign" (174). Viagem a Portugal explores the vulnerability of human lives as they collide with the impersonal exercise of power within the fortress-state, where "the law of unlimited hospitality" to which Jacques Derrida refers is superseded by laws that condition rights and obligations in the context of migration (77). Tréfaut's film in fact depicts cases in which subjects lose all their rights when confronted by the micro-fascistic power of the state. In the end, Viagem a Portugal takes an uncompromisingly ethical stance that denounces the psychological, emotional, and physical abuses frequently exacted upon travelers crossing borders. Maria arrives in Faro wearing a typical Ukrainian braid around her head (inspired by former leader Julia Timoshenko); in addition, she wears a good deal of makeup and has a slightly garish sartorial style that for Portuguese immigration officials suggests that she may be an Eastern European prostitute. This would be bad enough, but Maria's interactions with the immigration authorities take a nightmarish turn when they discover that her husband is a black African.

The dramatic centerpiece of Viagem a Portugal revolves around the interactions between the female immigration inspector, Maria, and Maria's husband. Through medium close-ups, we first see the passport control officer scrutinize Maria, whose image is reflected on the glass of the booth. The language barrier becomes immediately apparent, since Maria seems to speak only Russian and some very rudimentary French (but no Portuguese or English). She is subsequently taken aside to a room by the inspector and subjected to interrogation.

The passport control officer sizes Maria up while asking her basic questions about the languages she speaks and where her husband resides. Throughout this initial scene, subject position and point of view create dramatic tension and 


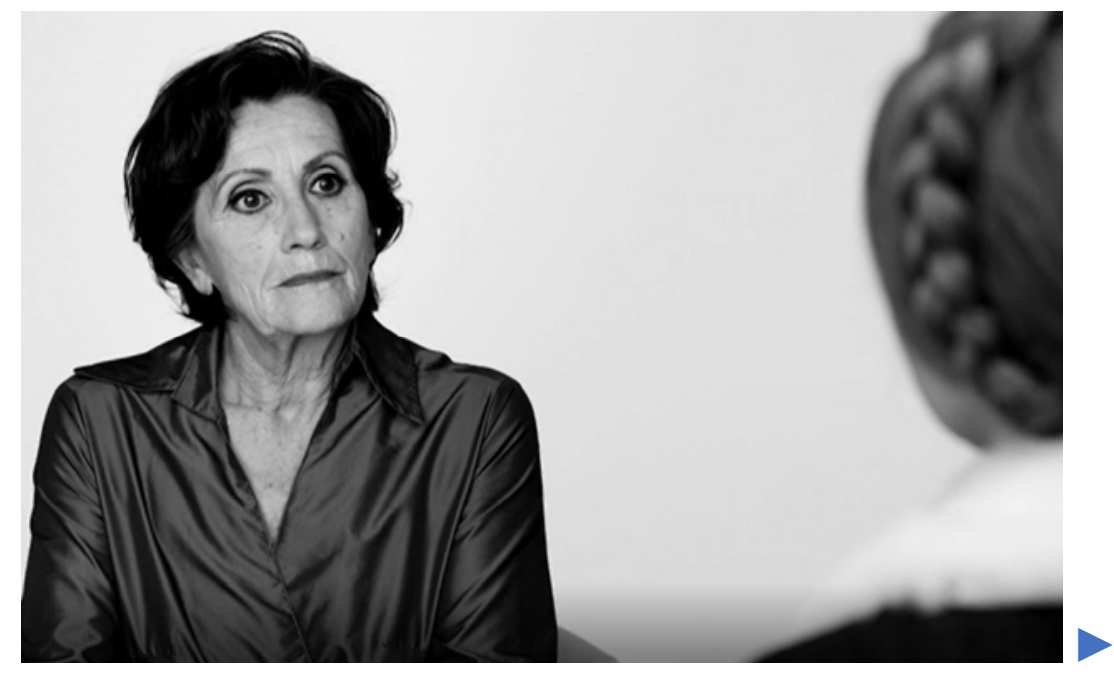

moments of acute sympathy for Maria as well as discomfort with respect to the inspector. At first, the audience occupies a third position, bearing witness to the exchange between Maria and the inspector. Its point of view is that of the camera placed behind Maria-the-migrant as she faces the inspector. Subsequently, the same question-and-answer sequence is repeated from the point of view of the inspector, and we observe that Maria appears more than a little nervous. This crucial exchange is seen through a series of close-up shots. Facial expressions on the part of both women are key during the entire scene. The inspector asks Maria whether she intends to live in Portugal, but Maria does not seem to understand the question. Eventually, Maria is informed that her husband must have a residency permit to live in Portugal. Tensions and misunderstandings ultimately escalate due to the lack of a common language. The language barrier proves to be practically and legally disempowering for Maria, leading to a series of arbitrary and abusive actions as well as disdainful statements directed at her. Throughout the initial interactions with the inspector, she becomes the object of a type of "linguistic violence" that ultimately dehumanizes her (Rosello 105). One may take as an example of this the statement made by the inspector in a phone conversation with her superior: "Ela não fala língua nenhuma, coitada." Maria is also objectified ("É um caso daqueles") and described as "aperaltada, parece uma boneca." Upon discovering that Maria's husband is Senegalese, she describes him as "retinto." 
When interrogated, Grégoire explains that he is a construction worker at the Expo 98 site, at which point the inspector asks him to reveal his hands. When the couple shows their marriage certificate, the inspector disqualifies it since it is written in Russian. The inspector then informs Grégoire that there are many young Eastern European women working in nightclubs throughout the Algarve region and that the authorities know that "os africanos andam metidos nisso."

There is a sequence of deeply humiliating moments for Maria and, by extension, her husband. The first one occurs when Maria is asked to open her suitcase so that officers might sift through her personal belongings. While glancing at Maria's photos, the inspector appears to react scornfully towards her biracial marriage. Later on, a male colleague also pries into Maria's photos and provocatively questions whether Grégoire is the father of what appears to be Maria's white son from a previous relationship. Maria explodes and snatches the photos from his hands, crying in Russian: "These are my photos taken from my purse. This is my life!" At another point, Maria is made to strip and endure a humiliating cavity search. The ordeal only escalates when she suffers a diabetic crisis without medical attention while held in isolated confinement.

Throughout Tréfaut's film, one witnesses the blatant debasing of human existence by the state, where the individual loses her rights by virtue of not being a citizen of the national-political territory into which she seeks entrance. Hannah Arendt calls attention to the paradox that emerges when individuals become "human beings in general" by losing or not possessing citizenship within a given nation-state. As she puts it, such a person represents "nothing but his own absolute unique individuality" (302). Agamben defines this through the "conceptual persona" of the homo sacer of Ancient Roman law (Campbell and Sitze 25). For the Romans, the homo sacer was a being outside the law, or in more contemporary terms, outside both the purview of the nation-state and the realm of human rights. Agamben posits the refugee or the camp prisoner as archetypes of such a being $(134 ; 171)$, and in Tréfaut's film, it is Maria-themigrant who embodies the homo sacer in relation to the sovereign power exercised at the micro-level by the immigration inspector and her colleagues.

Viagem a Portugal likewise contains scenes that seek to restore the migrant's humanity and counter the relentless cycle of humiliation and deprivation. For example, the photos of Maria and Grégoire once halfmockingly glanced at by the inspector come to fill the frame in a scene suffused 
with gentle and slightly dissonant piano music by the Hungarian composer György Sándor (the only instance in the film, besides the final credits, when there is extra-diegetic music).

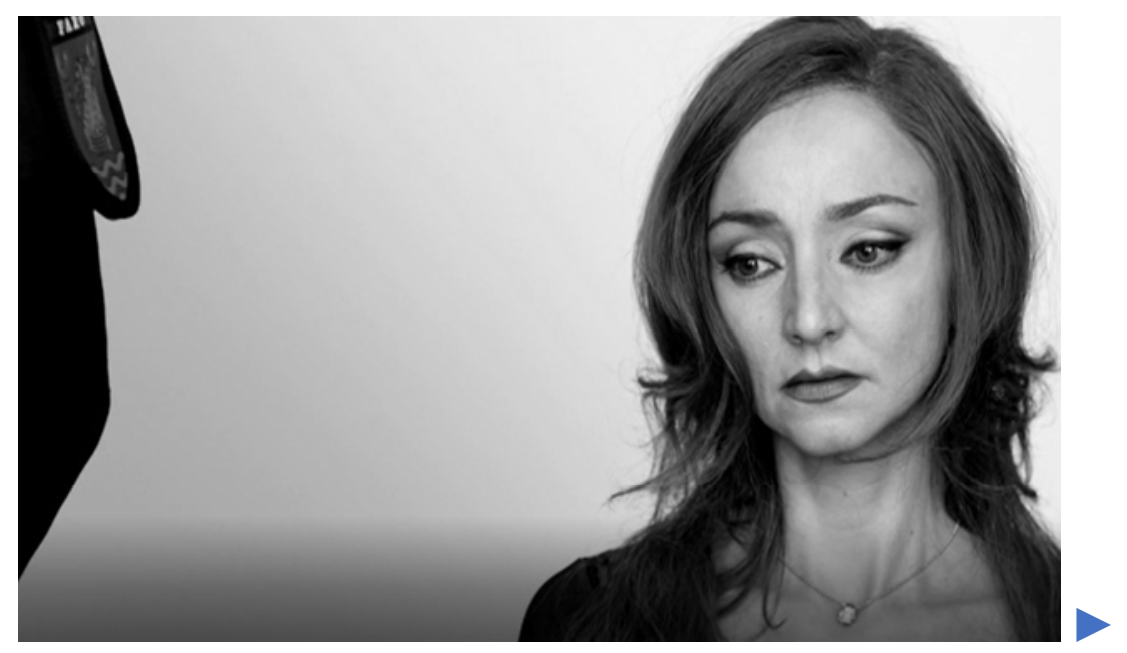

These are simultaneously beatific as well as mundane images of a joyous couple after their wedding, of Maria with her boy, of Grégoire as a construction worker in Portugal, and of Grégoire at iconic Portuguese cultural sites such as the Torre de Belém.

In Viagem a Portugal, one also witnesses the disdain that immigration authorities feel for a South Asian couple and the blatant discrimination they manifest in a dramatic scene of physical abuse against Brenda, a transgender Brazilian who claims to be in transit to Switzerland. Brenda, Maria, and Grégoire are all treated as criminals by the disciplining apparatus of the immigration checkpoint (Rosello 37). Amid these incidents there are also passing empathetic glances between migrants kept from entering Europe. Even the inspector, in a candid and private moment of emotional exhaustion, expresses pity for Maria; in another, she promises a skeptical Grégoire that "nós em Portugal somos humanos."

After the epilogue to Viagem a Portugal and before the final credits roll, intertitles reveal that the film is based on the real-life story of Tanya and Kita, who graduated from medical school at Donetsk University (Ukraine). After being expelled from Portugal, Tanya would ultimately return to live with her 
husband Kita. Since her return, she has worked in a variety of occupations including housecleaner, construction worker, translator at a refugee center, and immigrant hotline counselor. More recently, she has succeeded in having her medical diploma recognized in Portugal, while Kita has never again worked in the medical profession. ${ }^{13}$

One particularly poignant element of the film Viagem a Portugal is the timing of its story - the eve of 1998 - a watershed year in the history of contemporary Portugal, when the nation sought to celebrate its (new) status as a modern, predominantly middle-class, multicultural nation through the World Expo. By the same token, Tréfaut's film dramatically underscores the collision between Portuguese cultural narratives of hospitality, cordiality, and benign colonialism that have long informed its national identity and the laws that govern the flow of migrants into the state that not only place limits to hospitality, but that can be horrendously abused by officials.

The experiences of Maria in Viagem a Portugal, Alex and Paco in Terra extrangeira, and Serginho in Estive em Lisboa e lembrei de você all bear the marks of a borderland liminality, of not being entirely here nor there, in the grey zone of legality and illegality, and on the threshold of non-citizenship and citizenship. Even though Maria (or in real life, Tanya) is subjected to the power of the state and its abuse, she is ultimately able to overcome it and eventually integrate herself into Portuguese society. Alex and Paco, on the other hand, are doomed on the road to nowhere, while Serginho survives under a cloud of uncertainty in the streets of Lisbon. The experience of all migrating subjects examined in this essay, while tragic and precarious to varying degrees, nevertheless reveals both the perils and the promise of migration; it points at once to the fault lines that divide communities and the indispensable nature of human bonds.

\footnotetext{
${ }^{13}$ In the interview included with the DVD extras, Tréfaut explains his creative and aesthetic license in approaching this film, while affirming the facts that constitute the basis for Maria/Tanya's story. He states that Tanya was held in isolation for a significant amount of time at Faro International Airport without recourse to an interpreter or a lawyer. The intention of the Portuguese immigration authorities, it seems, was to send her to Russia, even though this was not her home country. A flight bound for Moscow waited for her on the tarmac for many hours. In Elsa Sertório's study on racism in Portugal, Tanya makes two separate statements regarding her experiences attempting to immigrate into Portugal (64-67, 89-91).
} 


\section{Works Cited}

Agamben, Giorgio. Homo Sacer: Sovereign Power and Bare Life. Translated by Daniel Heller-Roazen, Stanford UP, 1998.

Almeida, Carlos Helí de. Walter Salles: uma entrevista. Festival de Cinema Luso-Brasileiro Santa Maria da Feira, 2002.

António, João H.C., and Verónica Policarpo, editors. Os imigrantes e a imigração aos olhos dos portugueses: manifestações de preconceito $e$ perspectivas sobre a inserção de imigrantes. U Católica Portuguesa and Fundação Calouste Gulbenkian, 2001.

Arendt, Hannah. The Origins of Totalitarianism. Houghton Mifflin Harcourt, 1951.

Barahona, José, director. Estive em Lisboa e lembrei de você. David e Golias and Refinaria Filmes, 2015.

"Brasileiros fogem da crise em Portugal e pioram a economia." YouTube, uploaded by Folha de São Paulo (TV Folha), 15 July 2012, www.youtube.com/watch?v=gjqGHfLc44A.

Campbell, Timothy and Adam Sitze, editors. Biopolitics: A Reader. Duke UP, 2013.

Derrida, Jacques. Of Hospitality. Translated by Rachel Bowlby, Stanford UP, 2000.

Dunlevy, T'Cha. "Journey to Portugal Makes a Stopover in Customs Purgatory." The Gazette, 29 Apr. 2014, p. A17.

Esposito, Roberto. Communitas: The Origin and Destiny of Community. Translated by Timothy Campbell, Stanford UP, 2010.

Governo de Portugal. Relatório de imigração, fronteiras e asilo. Serviço de Estrangeiros e Fronteiras, 2013.

Holston, James. Insurgent Citizenship: Disjunctions of Democracy and Modernity in Brazil. Princeton UP, 2009.

Knudson-Vilaseca, Emily. "Embodying the Un/Home: African Immigration in Portugal and Spain.” Dissertation, U of Minnesota, 2007.

Lehnen, Leila. Citizenship and Crisis in Contemporary Brazilian Literature. Palgrave Macmillan, 2013. 
McMahon, Christina S. Recasting Transnationalism through Performance: Theatre Festivals in Cape Verde, Mozambique, and Brazil. Palgrave Macmillan, 2014.

Nagib, Lúcia. "Back to the Margins in Search of the Core: Foreign Land's Geography of Exclusion." The Brazilian Road Movie: Journeys of (Self) Discovery, edited by Sara Brandellero, U of Wales P, 2013, pp. 162-83.

Oricchio, Luiz Zanin. Cinema de novo: um balanço crítico da retomada. Espaço Liberdade, 2003.

Pinho, Alexandra. "Em busca de abrigo: o exílio em Terra estrangeira, de Walter Salles e Daniela Thomas.” Navegações, no. 5, 2012, pp. 88-93.

Rosello, Mireille. Postcolonial Hospitality: The Immigrant as Guest. Stanford UP, 2001.

Ruffato, Luiz. Mamma, son tanto felice. Record, 2005.

-. O mundo inimigo. Record, 2005.

—. Vista parcial da noite. Record, 2006.

—. O livro das impossibilidades. Record, 2008.

- Estive em Lisboa e lembrei de você. Companhia das Letras, 2009.

-. Domingos sem Deus. Record, 2012.

Sadlier, Darlene. "Leaving Home in Three Films by Walter Salles." The Brazilian Road Movie: Journeys of (Self) Discovery, edited by Sara Brandellero, U of Wales P, 2013, pp. 145-61.

Salles, Walter, and Daniela Thomas, directors. Terra estrangeira. Videofilmes, 1996.

Sertório, Elsa. Livro negro do racismo em Portugal. Dinossauro, 2001.

Strecker, Marcos. Na estrada: o cinema de Walter Salles. Publifolha, 2010.

"Tratados Portugal-Brasil." Alto Comissariado para a Imigração e Diálogo Intercultural, www.acidi.gov.pt/es-imigrante/legislacao/legislacaointernacional-nao-europeia/tratados-portugal---brasil. Accessed $11 \mathrm{Jul}$. 2013.

Tréfaut, Sérgio, director. Lisboetas. Faux, 2004.

—. Viagem a Portugal. Faux, 2011.

-. Alentejo, Alentejo. Faux, 2014. 